\title{
Chapter 7
}

\section{Photo-Electrochemical Reduction of $\mathrm{CO}_{2}$ to Solar Fuel: A Review}

\author{
Kinjal J. Shah ${ }^{\text {a, b, }}$, Shu-Yuan Pan ${ }^{\text {a, b }}$, Vimal Gandhi ${ }^{\text {c }}$, Pen-Chi Chiang ${ }^{\text {a, b,* }}$ \\ ${ }^{a}$ Graduate Institute of Environmental Engineering, National Taiwan University, Taiwan \\ ${ }^{\mathrm{b}}$ Carbon Cycle Research Center, National Taiwan University, Taipei City 10673, Taiwan \\ ${ }^{c}$ Department of Chemical Engineering \& Shah-Schulman Center for Surface Science and \\ Nanotechnology, Dharmsinh Desai University, Nadiad 387001, India \\ Email: kinjalshah8@gmail.com; pcchiang@ntu.edu.tw.
}

\begin{abstract}
Green chemistry and sustainable technology for $\mathrm{CO}_{2}$ capture, sequestration and utilization are urgently required to control $\mathrm{CO}_{2}$ growth. Amongst the available major methods (including chemical, photochemical, electrochemical and enzymatic methods), the photo-electrochemical method, especially development for solar to chemical or fuel technology, offers a green and potential alternative for efficient $\mathrm{CO}_{2}$ capture and conversion. This is a very active research area covering wide concepts and ideas under investigation with many barriers considering system engineering. This review will discuss the recent progress in this field as well as give a brief background on solar fuel conversion from captured $\mathrm{CO}_{2}$, suitable procedure for the solar fuel production and some of their critical components with case studies of methanol production.
\end{abstract}

Keywords

Green Chemistry, Solar Fuels, Photo-Electrochemical Solar Devices, Methanol, Carbon Utilization

\section{Contents}

1. Introduction: 212

2. Approaches to mitigate global climate change through $\mathrm{CO}_{2}$ utilization 
2.1 Homogeneous photo reduction by a molecular catalysis with Case Study.

2.2 Heterogeneous photoelectrochemical reduction by a semiconducting photo cathode with case study....

2.3 Electrochemical reduction by an electrolyzer powered by photovoltaic device with case study

2.4 Enzymatic photoinduced electrochemical reaction with case study

3. Challenges to solar fuel productions...............................................223

4. Future perspectives.................................................................................224

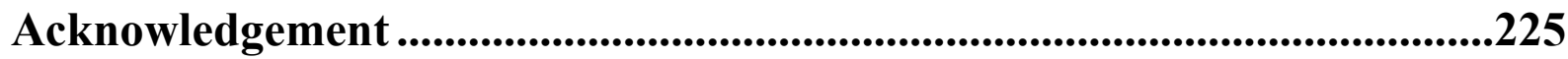

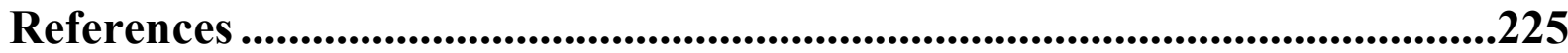

\section{Introduction:}

Green Chemistry (GC) is a relatively new emerging field with an objective to achieve environmental sustainability through design of a chemical product (chemistry) and processes (engineering) so as to reduce (a) generation of pollution at the source and (b) risk to human health and the environment [1-3]. GC basically works on 12 principles namely, prevention, atom economy, less hazardous chemical synthesis, designing safer chemicals, safer solvent, energy efficient, renewable feedstock, reduce derivatives, catalysis, design for degradation, pollution prevention and accident prevention [1,4]. If we correlate all these principles, the major focus of GC is on waste prevention and pollution prevention. In waste and pollution, emission of greenhouse gases is mostly reported, in which $\mathrm{CO}_{2}$ is a major concern (60\% contributed in greenhouse gases), as it is responsible for increasing earth temperature [5-7]. To mitigate global warming, Kyoto Protocol [8], Copenhagen accord [9, 10] and Paris agreements [11] are the major action taken by the world. Apart from those agreements, the International Energy Agency pointed out that in order to achieve the $\pm 2^{\circ} \mathrm{C}$ goal, $\mathrm{CO}_{2}$ capture and storage (CCS) technologies are neede $[9,12]$. It is therefore essential to develop a CCS technology and adding $\mathrm{U}$ (utilization) so that CCSU technologies can cope with the global demand of $\mathrm{CO}_{2}$ reduction [13]. Table 1 represents the advantages and disadvantages of the different $\mathrm{CO}_{2}$ capture and storage technologies. 
Table 1 Advantages and disadvantages of the different $\mathrm{CO}_{2}$ capture and storage technologies.

\begin{tabular}{|c|c|c|c|}
\hline $\begin{array}{l}\text { Capture } \\
\text { process }\end{array}$ & Advantages & Disadvantages & $\begin{array}{l}\text { Reference } \\
\mathrm{s}\end{array}$ \\
\hline $\begin{array}{l}\text { Post- } \\
\text { combustion }\end{array}$ & $\begin{array}{l}\text { Easy to retrofit into existing } \\
\text { plants. }\end{array}$ & $\begin{array}{l}\text { Capture efficiency depends on } \\
\mathrm{CO}_{2} \text { concentration. }\end{array}$ & {$[14,15]$} \\
\hline $\begin{array}{l}\text { Pre- } \\
\text { combustion }\end{array}$ & $\begin{array}{l}\text { Fully developed technology } \\
\text { and commercially accepted in } \\
\text { many industries. }\end{array}$ & $\begin{array}{l}\text { High capital and operating costs } \\
\text { for the system. }\end{array}$ & {$[14,16]$} \\
\hline $\begin{array}{l}\text { Oxyfuel- } \\
\text { combustion }\end{array}$ & $\begin{array}{l}\text { Very high } \mathrm{CO}_{2} \text { concentration } \\
\text { that enhances absorption } \\
\text { efficiency. }\end{array}$ & $\begin{array}{l}\text { Cryogenic } \mathrm{O}_{2} \text { production is } \\
\text { costly and corrosion problem } \\
\text { arises. }\end{array}$ & {$[17]$} \\
\hline $\begin{array}{l}\text { Chemical } \\
\text { looping } \\
\text { combustion }\end{array}$ & $\begin{array}{l}\mathrm{CO}_{2} \text { is the main combustion } \\
\text { without mixing of } \mathrm{N}_{2} \text { and thus } \\
\text { intensive air separation is not } \\
\text { require. }\end{array}$ & $\begin{array}{l}\text { Large scale operation is } \\
\text { expensive and under control } \\
\text { conditions. }\end{array}$ & {$[18]$} \\
\hline Absorption & $\begin{array}{l}\text { Most natural and highly } \\
\text { efficient technology. }\end{array}$ & $\begin{array}{l}\text { Absorption efficiency depends } \\
\text { on } \mathrm{CO}_{2} \text { concentration. }\end{array}$ & {$[13,19]$} \\
\hline Adsorption & $\begin{array}{l}\text { Process is reversible and } \\
\text { adsorbent can be recycled. }\end{array}$ & $\begin{array}{l}\text { Higher energy cost for } \mathrm{CO}_{2} \\
\text { desorption and reutilization of } \\
\text { sorbent. }\end{array}$ & $\begin{array}{l}{[19} \\
20,21]\end{array}$ \\
\hline $\begin{array}{l}\text { Membrane } \\
\text { separation }\end{array}$ & $\begin{array}{l}\text { Separation of gases could be } \\
\text { possible. }\end{array}$ & $\begin{array}{l}\text { Operational problems such as } \\
\text { low fluxes and fouling. }\end{array}$ & {$[22,23]$} \\
\hline $\begin{array}{l}\text { Hydrate } \\
\text { based } \\
\text { separation }\end{array}$ & Low energy requirement. & Cost and storage is an issue. & [24] \\
\hline $\begin{array}{l}\text { Cryogenic } \\
\text { distillation }\end{array}$ & $\begin{array}{l}\text { Adopted for many years in } \\
\text { industry for } \mathrm{CO}_{2} \text { recovery. }\end{array}$ & High energy consumption. & {$[14,25]$} \\
\hline $\begin{array}{l}\text { Unmineable } \\
\text { coal bed } \\
\text { storage }\end{array}$ & $\begin{array}{l}\mathrm{CO}_{2} \text { can be injected into deep } \\
\text { coal beds to recover methane. }\end{array}$ & $\begin{array}{l}\text { Many of coal have low } \\
\text { permeability that make process } \\
\text { not applicable. }\end{array}$ & {$[26,27]$} \\
\hline $\begin{array}{l}\text { Enhanced } \\
\text { oil recovery } \\
\text { in oil and } \\
\text { gas } \\
\text { reservoirs }\end{array}$ & $\begin{array}{l}\text { There is an economic } \\
\text { incentive to inject } \mathrm{CO}_{2} \text { and } \\
\text { recovered oil. }\end{array}$ & $\begin{array}{l}\text { Transportation } \mathrm{CO}_{2} \text { for storage } \\
\text { and handling is challenging. }\end{array}$ & {$[14,28]$} \\
\hline $\begin{array}{l}\text { Storage in } \\
\text { saline } \\
\text { aquifers }\end{array}$ & $\begin{array}{l}\text { Dissolved } \mathrm{CO}_{2} \text { react with } \\
\text { metals and prepared carbonate } \\
\text { precipitates. }\end{array}$ & $\begin{array}{l}\text { Conversion rate is less and } \\
\text { unpredictable. }\end{array}$ & [29] \\
\hline
\end{tabular}




\begin{tabular}{|l|l|l|l|}
\hline $\begin{array}{l}\text { Deep ocean } \\
\text { storage }\end{array}$ & $\begin{array}{l}\text { Compare to land, the sea part } \\
\text { is } 70 \% \text { bigger }\end{array}$ & $\begin{array}{l}\text { Injecting large amount of } \mathrm{CO}_{2} \\
\text { may affect the seawater } \\
\text { chemistry and marine life. }\end{array}$ & {$[30,31]$} \\
\hline $\begin{array}{l}\text { In-situ } \\
\text { carbonation }\end{array}$ & $\begin{array}{l}\text { It offers economic advantages } \\
\text { over other processes, because } \\
\text { no chemical plant is required, } \\
\text { as it involves simple } \\
\text { conversion to carbonate when } \\
\text { reacted with rock. }\end{array}$ & $\begin{array}{l}\text { Limited knowledge of rock, and } \\
\text { conversion methods are still } \\
\text { nucleated. }\end{array}$ & {$[13]$} \\
\hline
\end{tabular}

\section{Approaches to mitigate global climate change through $\mathrm{CO}_{2}$ utilization}

Atmospheric $\mathrm{CO}_{2}$ utilization can be done in two ways i.e. direct use of $\mathrm{CO}_{2}$ and conversion of $\mathrm{CO}_{2}$ to chemicals [32]. In the past years, $\mathrm{CO}_{2}$ has been utilized in soft drink, food, fire-extinguishers, propellant, or as a fluid/solvent in various processes like drying-cleaning, separation, packaging, etc. [33]. However, emission rates are too high and there is still as need for new areas to store $\mathrm{CO}_{2}$ such as feedstock to biofuel [34], carbonized cement materials [35], direct utilization of $\mathrm{CO}_{2}$ via microalgae [34], $\mathrm{CO}_{2}$ utilization in production of some special chemical products, energy products such as methanol, Dimethyl carbonate, Dimethyl ether etc. (see fig 1) [13, 32]. However, $\mathrm{CO}_{2}$ still has certain disadvantages as a chemical reactant due to its inert, highly stable, nonreactive, and low Gibbs free energy properties [36]. Each potential conversion of $\mathrm{CO}_{2}$ requires energy input; therefore, the life cycle assessment of such utilization processes or concepts must be applied to ensure a neutral or even negative carbon emission.

While considering GC mechanism and growth of global fuel demands, many research groups have tried conversion of fuels to organic molecules by sunlight [37-40]. Fuels that are obtained from utilizing solar light are called solar fuel. This is not a new mechanism but rahter a natural phenomenon where, solar energy and $\mathrm{CO}_{2}$ are captured by plants to convert complex molecules such as glucose [37], which are then used as feedstock for production of biofuels. During the process, water splits into the oxygen and hydrogen, where oxygen is available for us to breathe and hydrogen combines with carbon to produce sugar [41]. Therefore, from an energy point of view, the synthesis of organic molecules represents a potential way to store hydrogen in the form of solar energy to chemical bond [42]. In the process, multiple electrons and protons are required to produce useful products such as methane or methanol [40]. There are several ways to reduce $\mathrm{CO}_{2}$ with use of solar energy, and these methods can be divided into four major categories namely:

1.Homogeneous photo reduction by a molecular catalysis

2.Heterogeneous photo-electrochemical reduction by a semiconducting photo cathode 
3.Electrochemical reduction by an electrolyzer powered by a photovoltaic device 4.Enzymatic photo-induced electrochemical reaction

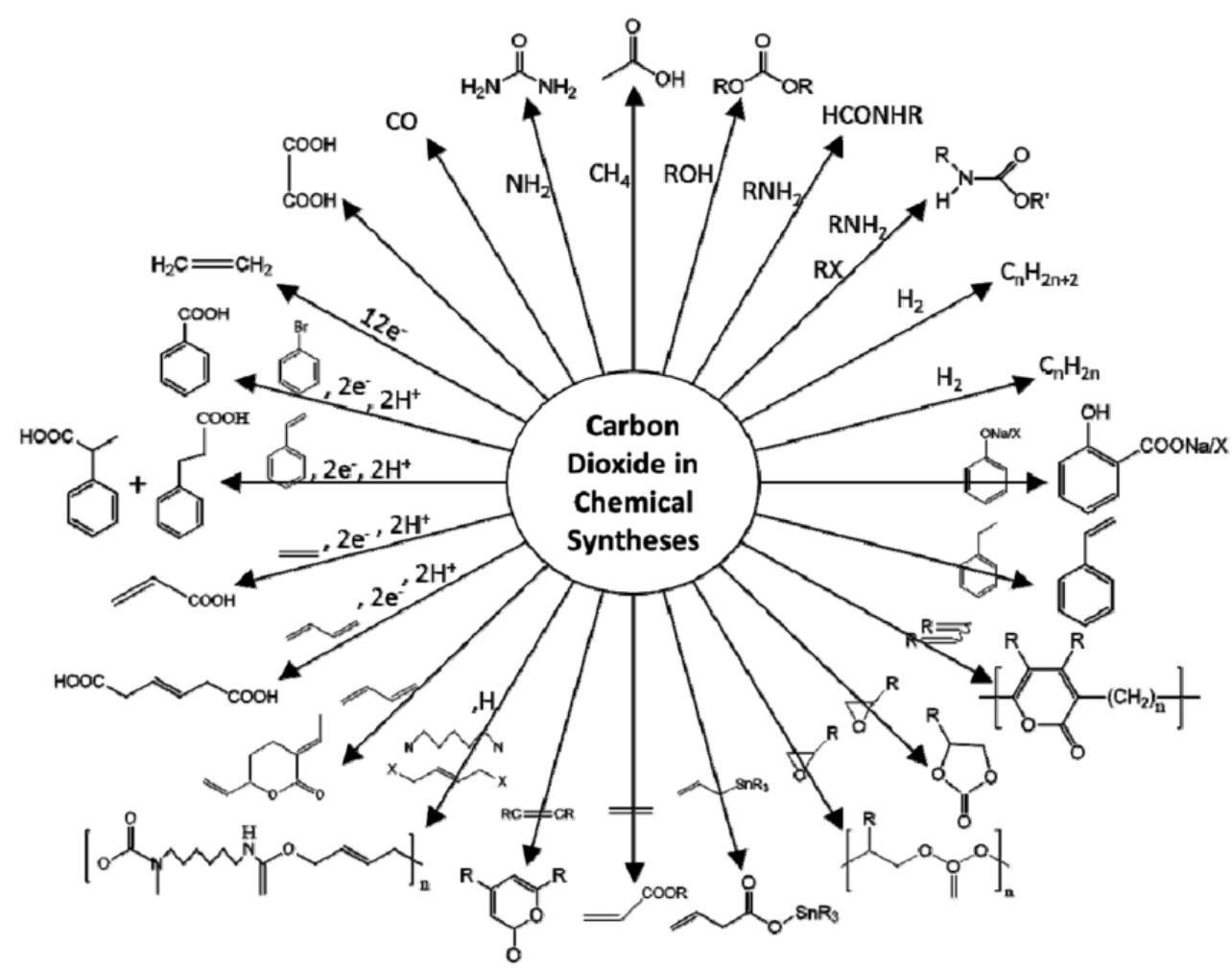

Figure 1. Utilization of $\mathrm{CO}_{2}$ to synthesize various chemicals [Adapted Figure from 13].

\subsection{Homogeneous photo reduction by a molecular catalysis with Case Study}

A homogeneous $\mathrm{CO}_{2}$ photoreduction system consists of a molecular catalyst; light absorber, sacrificial electron donor, and/or electron relay [43]. In the mechanism of photocatalytic reduction photosensitizer (P) and donor (D) are mostly involved to accomplish the reactions, where, $\mathrm{P}$ convert to $\mathrm{P} *$ (excited state) after absorbing radiation in the ultraviolet or visible region. After that, the excited state is reductively quenched by a sacrificial donor (D) generating a singly reduced photosensitizer $\left(\mathrm{P}^{-}\right)$and oxidized donor $\left(\mathrm{D}^{+}\right)$. The $\mathrm{P}^{-}$now transfers its electron to the catalyst to generate a reduced catalyst species. In most cases photosensitizer and catalyst have the same material with coordinated transition metal complexes. Ruthenium(II) trisbipyridine $\left(\left[\mathrm{Ru}(\mathrm{bipy})_{3}\right]^{2+}\right)$ is the most often applicable transition metal complex due to its high visible light absorption capacity and photo stability [44]. The electron transfer mechanism has been described as bellow equations.

$$
\mathrm{P}+h v \rightarrow \mathrm{P}^{*},
$$




$$
\begin{aligned}
& \mathrm{P}^{*}+\mathrm{D} \rightarrow \mathrm{P}^{-}+\mathrm{D} \\
& \mathrm{P}^{-}+\text {catalyst } \rightarrow \mathrm{P}+\text { catalyst }^{-} \\
& \text {catalyst }^{-}+\mathrm{CO}_{2} \rightarrow \text { Products }+ \text { catalyst. }
\end{aligned}
$$

Case Study: Homogeneous photocatalytic reduction of $\mathrm{CO}_{2}$ to methanol and formate using ruthenium(II) trisphenanthroline as chromophore and pyridine as catalyst [45]. In order to produce formic acid, formaldehyde and methanol form $\mathrm{CO}_{2}$, two, four and six electron were needed respectively to complete the reaction (Refer Eq. 5-7) [40, 46, 47]. However, multiple electron and proton transfer is necessary to produce methanol compared to formic acid and carbon monoxide (Refer Eq. 8) [43].

$$
\begin{aligned}
& \mathrm{CO}_{2}+2 \mathrm{H}^{+}+2 \mathrm{e}^{-} \rightarrow \mathrm{HCOOH}, \\
& \mathrm{CO}_{2}+4 \mathrm{H}^{+}+4 \mathrm{e}^{-} \rightarrow \mathrm{HCHO}+\mathrm{H}_{2} \mathrm{O} \\
& \mathrm{CO}_{2}+6 \mathrm{H}^{+}+6 \mathrm{e}^{-} \rightarrow \mathrm{CH}_{3} \mathrm{OH}+\mathrm{H}_{2} \mathrm{O} \\
& \mathrm{CO}_{2}+2 \mathrm{H}^{+}+2 \mathrm{e}^{-} \rightarrow \mathrm{CO}+\mathrm{H}_{2} \mathrm{O} .
\end{aligned}
$$

Thus, in the reaction mechanism, proper electron transfer is necessary which can be achieved by chromophore, pyridine and sacrificial donor system [48]. In the reaction, ascorbic acid can be used as a sacrificial reductant (electron supply), using visible light irradiation at $470 \pm 20 \mathrm{~nm}$. During the process of excitation, both chromophore $\left[\mathrm{Ru}(\mathrm{phen})_{3}\right]^{2+}$ and pyridine shows metal-to-ligand charge transfer (MLCT) in the 400-500 $\mathrm{nm}$ region which yield long lived MLCT states that transiently localize the electron on one of the ligands (phen) and the hole on the metal center $\left[\mathrm{Ru}^{\mathrm{III}}(\mathrm{phen})_{2}\left(\mathrm{phen}^{-}\right)\right]^{2+}[49]$. However, the ratio of pyridine to chromophore is an important factor to generate the necessary six electrons. It was found that the turnover number during the process is 0.9 electron per $\left[\mathrm{Ru}(\mathrm{phen})_{3}\right]^{2+}$, thus, pyridine was presented at large extend $(1: 200)$ to obtained $31 \pm 3 \mu \mathrm{M}$ after $6 \mathrm{~h}$ of irradiation [45]. Additionally, the presence of potassium salts $(\mathrm{KCl})$ can enhance the yield of formate and methanol compared to electrolyte-free solutions. This is because ion-pairing between carboxylate functions with alkali and alkali earth metal cations can stabilize the transition states involving $\mathrm{CO}_{2}$ reduction in transition-metal complexes coordinating $\mathrm{CO} 2$ ligands [50, 51]. Although photocatalytic reduction of $\mathrm{CO}_{2}$ to solar fuel production has been achieved, much more progress is needed before it can become a practical commercial process as different solvent, electron donors, photosensitizers, and light sources have been deployed by various groups [40], 
but conversion ratio are still under consideration. More mechanistic work must be done in order to increase the stability and rates.

\subsection{Heterogeneous photoelectrochemical reduction by a semiconducting photo cathode with case study}

A heterogeneous $\mathrm{CO}_{2}$ photoreduction system consists of a p-type or n-type semiconducting electrodes, which is utilized for $\mathrm{CO}_{2}$ reduction [52-53], and an electrolyte. The semiconducting electrodes are containing band gap and thus they are different from a metallic electrode (with no band gap). Many semiconductors have been utilized as electrodes for $\mathrm{CO}_{2}$ reduction and they are categorized depending on the charge densities of electrons and holes [54-61]. Among them, semiconductors with donor impurities that provide electrons to the lattice are n-type semiconductors with electrons as the majority charge carrier. On the other hand, semiconductors with acceptor impurities that remove electrons from the lattice are p-type semiconductors. In which, p-type semiconducting electrodes can act as photocathodes for photo assisted $\mathrm{CO}_{2}$ reduction and it is classified in three major classes. (1) Direct heterogeneous $\mathrm{CO}_{2}$ reduction by a biased semiconductor photo cathode; (2) heterogeneous $\mathrm{CO}_{2}$ reduction by metal particles on a biased semiconductor photocathode and (3) heterogeneous $\mathrm{CO}_{2}$ reduction by a molecular catalyst attached to the semiconductor photocathode surface.

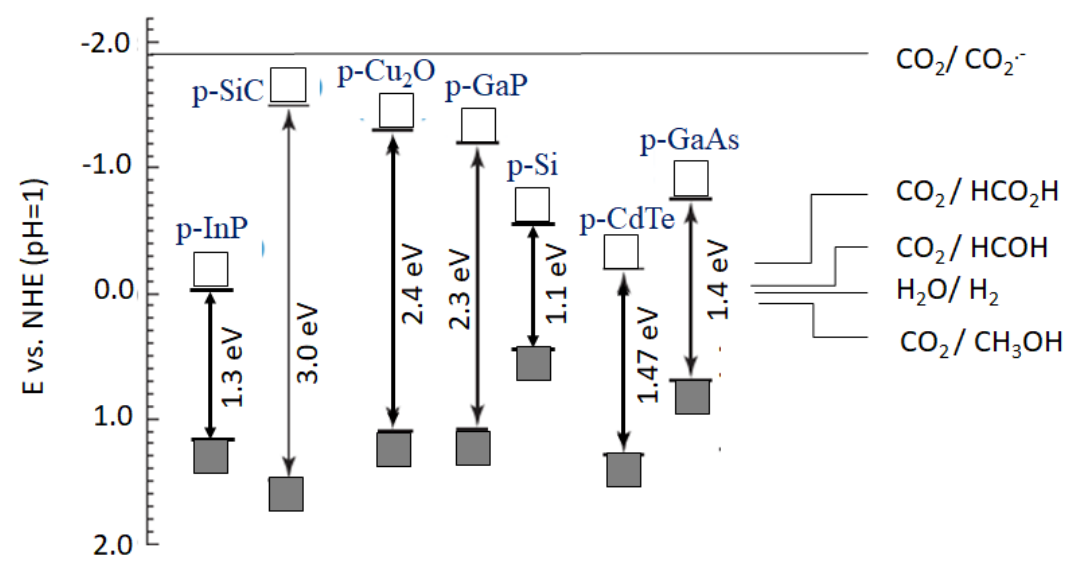

Figure 2. Conduction band (white square) and valance band (gray square) potentials of several $p$-type semiconductors at $\mathrm{pH}=1$ versus a normal hydrogen electrode (NHE), with the potentials of several $\mathrm{CO}_{2}$ and water redox potential of the homogeneous catalysts $[54,55,58,60-61]$.

Figure 2 shows band edge position versus an NHE for several common p-type semiconductor electrode with $\mathrm{CO}_{2}$ reduction potential for different products at $\mathrm{pH}=1$. The value of conduction band for $\mathrm{CO}_{2}$ to $\mathrm{CO}_{2}^{-}$, with single electron reduction product is much higher than other products such as $\mathrm{HCOOH}, \mathrm{HCHO}$ and $\mathrm{CH}_{3} \mathrm{OH}$. Moreover, pH, co- 
catalyst and surfaces of electrodes are affecting the values of the band gaps [43]. Additionally, aqueous and non-aqueous solvents such as acetonitrile, dimethylformamide, dimethyl sulfoxide and methanol have been utilized for direct $\mathrm{CO}_{2}$ photoelectochemical reduction $[62,63]$. Among them, methanol has been utilized as solvent for $\mathrm{CO}_{2}$ in Rectisol process due to its higher solubility [64-65]. In water hydration of $\mathrm{CO}_{2}$ is different than solvents such as formation of bicarbonate $\left(\mathrm{HCO}_{3}{ }^{-}\right)$and carbonate $\left(\mathrm{CO}_{3}{ }^{2-}\right)$ at $\mathrm{pH} 7-8$ and $>11.5$, respectively $[43,66]$. In order to produce solar fuel, high pressure reduction of $\mathrm{CO}_{2}$ on $\mathrm{p}$ type semiconducting photocathode $\mathrm{p}-\mathrm{GaAs}$ and $\mathrm{p}-\mathrm{GaP}$ was performed to produce $\mathrm{HCOOH}$ or $\mathrm{HCHO}[67,68]$. However $\mathrm{CH}_{3} \mathrm{OH}$ selectivity is still a challenge, it is obtained by increase concentration of carbonic acid, higher pressure and presence of $\mathrm{Na}_{2} \mathrm{CO}_{3}, \mathrm{Na}_{2} \mathrm{SO}_{4}$ and $\mathrm{HClO}_{4}$ with water medium $[67,69]$. The main product for $\mathrm{CO}_{2}$ reduction in most non-aqueous solvents on these semiconductor surfaces is $\mathrm{CO}$ with varying Faradaic efficiency, except in methanol with a $\mathrm{p}$-GaAs photocathode. In that $\mathrm{p}$-type semiconductors such as $\mathrm{p}-\mathrm{Si}, \mathrm{p}-\mathrm{GaP}, \mathrm{p}-\mathrm{InP}$, and $\mathrm{p}-\mathrm{GaAs}$, CdTe is notable for its low $\mathrm{CO}_{2}$ reduction (CO) onset potential and high quantum efficiency [43, 70]. Often, metal nano particles along with photocathode can improve the performance. The $\mathrm{Au}, \mathrm{Ag}, \mathrm{Pd}, \mathrm{Cu}$, and $\mathrm{Ni}$ have been utilized with $\mathrm{p}$-InP photocathode to form methanol from $\mathrm{CO}_{2}$, whereas for particulate- $\mathrm{Pb} / \mathrm{p}$-InP, the major product is $\mathrm{HCOOH}$ [71].

Case Study: Photo electrochemical reduction of $\mathrm{CO}_{2}$ to methanol using a single crystal catalyzed p-GaP and p-GaAs based semiconductor electrode [67]. In the system of a high pressure irradiation cell, an anode was bright platinum, glassy carbon or carbon road and the cathode was a p-GaP single crystal. A tungsten halogen lamp or Xe lamps with a maximum output of 7 suns have been utilized in these experiments. In the experiments, $\mathrm{CO}_{2}$ reduction to formic acid and other organic products was achieved on negatively biased p-type semiconductor electrodes, which absorb in the visible light. Highest faradaic yield of reduction products, $80 \%$ was obtained with a $\mathrm{p}$-GaP cathode at a cathodic current of $-1.00 \mathrm{~V}$ with $0.5 \mathrm{M} \mathrm{Na}_{2} \mathrm{CO}_{3}$ under $8.5 \mathrm{~atm}$ pressure. While (-780) to (1050) potential, maximum conversion of $\mathrm{CH}_{3} \mathrm{OH}$ form $\mathrm{HCOOH}$ with nearly $37 \%$ yield. With the increased rate of the electric charge passed and lower potential, conversion rate decreases. Under elevated $\mathrm{CO}_{2}$ pressure, it was possible to reached $80 \%$ Faradaic yields with the presence of a buffer such as $\mathrm{LiHCO}_{3}$ and $\mathrm{NaHCO}_{3}$. In that case adsorption of $\mathrm{CO}_{2}$ on the surface of the semiconductor electrode such as $\mathrm{GaP}$ increased. While presence of $\mathrm{HClO}_{4}(0.1 \mathrm{M})$ and $\mathrm{CO}_{2}$ at atmosphere pressure $3 \mathrm{~atm}$, conversion of $\mathrm{CH}_{3} \mathrm{OH}$ was 61.0 $\mu$ mol. With increase electric charge and pressure to $10 \mathrm{~atm}$, formation of $\mathrm{HCOOH}$ was increased with decreased formation of $\mathrm{CH}_{3} \mathrm{OH}$. Thus it can be conclude that the Faradaic yield decreases when the reaction is carried out at a more negative potential. Good selectivity has also been observed at a catalyzed p-InP photoelectrochemical cell for the 
production of formic acid. While, these materials have shown the highest selectivity for the production of methanol only at exceptionally high potentials. Under improved experimental conditions, near $100 \%$ faradaic efficiency of $\mathrm{CH}_{3} \mathrm{OH}$ was obtained with p$\mathrm{GaP}$ semiconductor at potentials greater than $300 \mathrm{mV}$ below the standard potential of $0.52 \mathrm{~V}$ vs SCE at $\mathrm{pH}$ of 5.2 [67].

\subsection{Electrochemical reduction by an electrolyzer powered by photovoltaic device with case study}

A photochemical solar collector (device) was built, to assess the capability of various polycrystalline semiconductors for the photo assisted reduction of carbon dioxide and water under sunlight [72]. There are only few examples where PV-powered commercial electrolyzers have been used for $\mathrm{CO}_{2}$ reduction to energy products rather than hydrogen generation $[73,74]$. The idea to power an electrolyzer by a PV device was first proposed by Bard \& Fox for the water splitting electrolyzer [75]. In the electrolyzer system, generated power from a photovoltaic generator has been supplied to electrolyzer (See Fig. 3). Electrolysis involves the conversion of reactants to products using a series of redox reactions in which one species loses electrons and is oxidized on the anode while another species gains electrons and is reduced on the cathode. In general case of direct conversion by direct methanol fuel cells (DMFC), $\mathrm{CO}_{2}$ is converted to $\mathrm{CO}$ without the use of an external hydrogen source and followed by the product such as methanol [76]. On the cathode side, the reactions are much more complex as $\mathrm{CO}_{2}$ can be reduced to a variety of products depending on the number of electrons donated (Refer Eq. 9). While on the anode side, water undergoes a four electron oxidation (Refer Eq. 10). This yields an overall reaction in a $\mathrm{CO}_{2}$ electrolyzer which is the combination of both water and $\mathrm{CO}_{2}$ to form high value electro-fuels (Refer Eq. 11). The general equation for this reaction is shown below.

$$
\begin{aligned}
& \text { Reduction: } \mathrm{CO}_{2}+\mathrm{nH}^{+}+\mathrm{ne}^{-} \rightarrow \mathrm{CH}_{x} \mathrm{O}_{y}+\mathrm{H}_{2} \mathrm{O} \text {, } \\
& \text { Oxidation: } 2 \mathrm{H}_{2} \mathrm{O} \rightarrow \mathrm{O}_{2}+4 \mathrm{H}^{+}+4 \mathrm{e}^{-}, \\
& \text {Overall: } \mathrm{CO}_{2}+\mathrm{nH}_{2} \mathrm{O} \rightarrow \mathrm{CH}_{x} \mathrm{O}_{y}+\mathrm{O}_{2} .
\end{aligned}
$$

The conversion can be affected by voltage, current, temperature, and gas output pressure parameters. An idealized diagram of $\mathrm{CO}_{2}$ electrolysis device, including photovoltaic compartment is shown in Fig. 3. Typically $\mathrm{CO}_{2}$ electrolysis is performed in modified two-compartment electrochemical cell that contains both anode and cathode materials in individual chambers separated by an ion conducting membrane [77]. The membrane is crucial in separating reaction products preventing the oxidation of the cathode products 
on the anode during operation. A voltage is applied between both electrodes to execute reaction. The equilibrium potential is fixed for the relevant oxidation and reduction reaction to occurred.

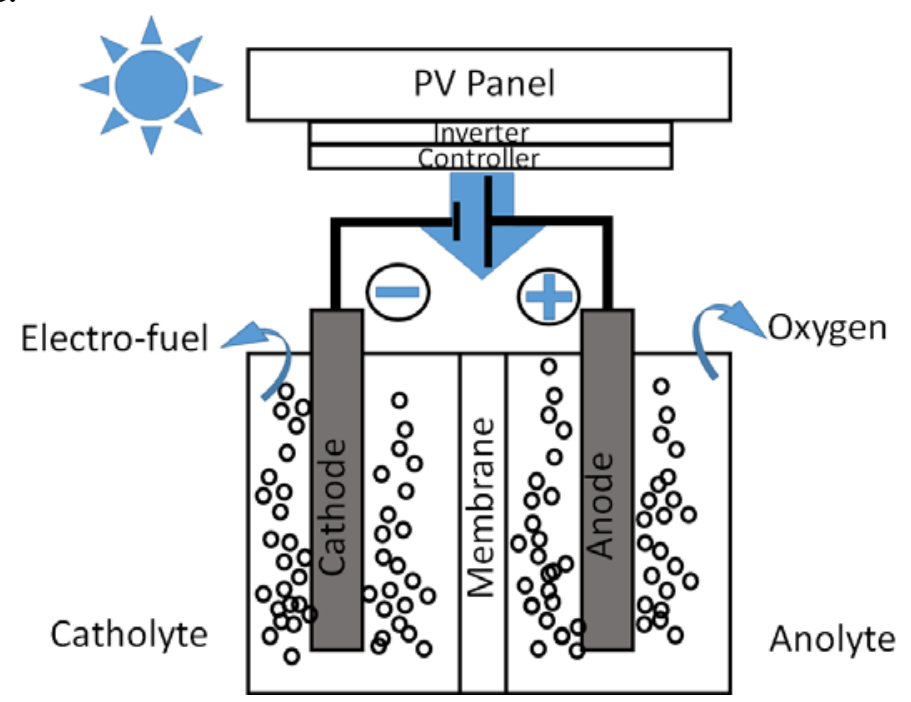

Figure 3. Schematic of $\mathrm{CO}_{2}$ electrolyzer powered by photovoltaic device components.

Case Study: Catalytic conversion of $\mathrm{CO}$ and $\mathrm{CO}_{2}$ into methanol through a photocell [78]. In the system redox reaction being composed through the reduction of $\mathrm{CO}$ or $\mathrm{CO}_{2}$ into methanol and the oxidation of Everitt's salt $\left(\mathrm{ES}, \mathrm{K}_{2} \mathrm{Fe}^{\mathrm{II}}\left[\mathrm{Fe}^{\mathrm{II}}(\mathrm{CN})_{6}\right]\right)$ to Prussian blue (PB, $\left.\mathrm{KFe}^{\mathrm{III}}\left[\mathrm{Fe}^{\mathrm{II}}(\mathrm{CN})_{6}\right]\right)$. In the electrolysis cell, n-type $\mathrm{TiO}_{2}$ is used as anode and an ESmodified electrode (ES coated on pt plate) is used as cathode. While solar sell generating $5 \mathrm{~W}$ power was utilized during the mechanism. The catalyst solution utilized in the system are prepared by dissolving a metal complex, methanol and $0.1 \mathrm{M} \mathrm{KCl}$. The reaction mechanism to convert methanol has been presented as per following equations (Refer Eq. $12,13)$.

$$
\begin{aligned}
& \mathrm{CO}+4 \mathrm{ES}+4 \mathrm{H}^{+} \leftrightarrow \mathrm{CH}_{3} \mathrm{OH}+4 \mathrm{~PB}+4 \mathrm{~K}^{+}, \\
& \mathrm{CO}_{2}+6 \mathrm{ES}+6 \mathrm{H}^{+} \leftrightarrow \mathrm{CH}_{3} \mathrm{OH}+6 \mathrm{~PB}+6 \mathrm{~K}^{+}+\mathrm{H}_{2} \mathrm{O} .
\end{aligned}
$$

In the reaction mechanism of equation 12 and 13, formation of methanol was obtained with transfer of 4 and 6 electron respectively. After the experiments, it was concluded that $\mathrm{CO}$ and $\mathrm{CO}_{2}$ can be converted to methanol except at the cell voltage of $1.0 \mathrm{~V}$. The lack of formation of methanol at this voltage is ascribed the incomplete regeneration of ES in reaction. Meanwhile, ferrous complex with nitroso-R salt and tiron give high current efficiency of the methanol formation compared to cobalt(II)-tiron and iron(II)phthalic acid complexes leading to no reduction of $\mathrm{CO}_{2}$. Hence, the validity of a metal 
complex as the homogeneous catalyst is closely concerned with the coordination chemistry of the metal complex in the solution [79].

\subsection{Enzymatic photoinduced electrochemical reaction with case study}

Among the existing methods, the enzymatic method, offers a green and potent alternative for efficient $\mathrm{CO}_{2}$ conversion due to its superior stereo-specificity and region/chemoselectivity [80]. In nature, photoreaction can be seen in leafs, where glucose (organic molecule) is formed with the utilization of $\mathrm{CO}_{2}$ [37]. In order to allow biological evolution to proceed efficiently, cells adopt six major routes (including the Calvin cycle, reductive citric acid cycle, reductive acetylCoA route, 3-hydroxypropionate cycle, 3hydroxypropionate/4-hydroxybutyrate cycle and dicarboxylate/4-hydroxybutyrate cycle) for presenting the $\mathrm{CO}_{2}$ metabolic process [81]. In all six major routes, the $\mathrm{CO}_{2}$ fixation/conversion reaction is particularly important, in which oxidoreductases (i.e., formate dehydrogenase ( $\mathrm{FDH}), \mathrm{CO}_{2}$ reductase, $\mathrm{CODH}$, remodeled nitrogenase, etc.), synthases and lyases (i.e., carbonic anhydrase) play crucial roles in accelerating the reaction rate as well as create appropriate physicochemical microenvironments to suppress the denaturation of enzymes [40, 82]. An oxidoreductase is an enzyme that catalyzes the transferring of electrons from one molecule (the reductant or electron donor) to another (the oxidant or electron acceptor) and a lyase is an enzyme that catalyzes the breaking of chemical bonds and then generates a new double bond or a new ring structure. Equation 14 and 15 represents the formation of formate and $\mathrm{CO}$ through FDH reductase. During the redox reaction, NADPH/NADP+ or NADH/NAD + is employed as an essential cofactor [40].

$$
\begin{aligned}
& \mathrm{CO}_{2}+2 \mathrm{e}^{-}+\mathrm{H}^{+} \rightarrow \mathrm{HCOO}^{-} \\
& \mathrm{CO}_{2}+2 \mathrm{e}^{-}+2 \mathrm{H}^{+} \rightarrow \mathrm{CO}+\mathrm{H}_{2} \mathrm{O} \\
& \mathrm{CO}_{2}+\mathrm{H}_{2} \mathrm{O} \rightarrow \mathrm{H}^{+}+\mathrm{HCO}_{3}^{-} .
\end{aligned}
$$

A similar system has been deployed to synthesize a solar fuel from $\mathrm{CO}_{2}$ with integrating several kinds of enzymes (including the enzyme that directly fixes/converts $\mathrm{CO}_{2}$ and other enzymes that conduct the subsequent reactions) to implement multi-enzyme reactions. In natural photosynthesis of higher green plants and oxygenic photosynthetic cyanobacteria, the photosynthesis reaction consists of two photosystems such as Photosystem I and II [37]. Photosystem I performs the photoreduction of NADP ${ }^{+}$to NADPH, whereas photosystem II produces oxygen through water oxidation. The photosystem II in the photosynthesis protein acts as an oxidation catalyst of water [83, 84]. Through combining both reaction, conversion of an artificial leaf can be achievable. 
In ordered to convert the ethanol end product, multi enzyme system such as FDH, aldehyde dehydrogenase (AlDH) and alcohol dehydrogenase (ADH) have been utilized (Fig. 4). However, equation 16 represent the lyase reaction. In which, $\mathrm{CO}_{2}$ convert to bicarbonate through changing structure/elimination. Carbonic anhydrase, existing in a mammals, plants, algaes and bacteria is a typical lyase, which is mainly responsible for the (inter) conversion between $\mathrm{CO}_{2}$ and bicarbonate to maintain the acid-base balance in blood and other tissues.

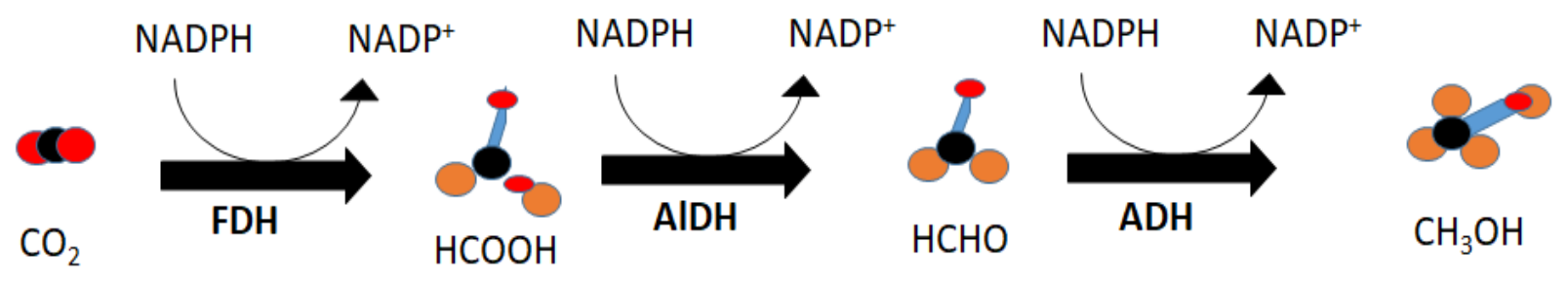

Fig. 4. $\mathrm{CO}_{2}$ reduction to methanol in water promoted by $\mathrm{FDH}, \mathrm{AlDH}$ and $\mathrm{ADH}$.

Case Study: Photoinduced enzymatic conversion of $\mathrm{CO}_{2}$ gas to solar fuel on cellulose nanofiber film [40]. In the multi-enzymatic system (FDH, AlDH and ADH induced on fiber), porphyrin is utilized as photosensitizer and dendrimer is utilized as carrier of electron/proton. The carbon capture on 2,2,6,6-tetramethylpiperidine-1-oxyl (TEMPO) oxidase cellulose nano fiber and dendrimer was successfully developed and now the utilization through photoinduced enzymatic system was developed successfully [85-86]. In the system, tetrakis-(4-carboxyphenyl)porphyrin (TCPP) have been deployed on TEMPO oxidized cellulose nano fiber (TOCNF) film through chemical bonding along with amine-terminated fourth generation poly(amido amine)(PAMAM) dendrimer. Apart from dendrimer and TCPP, multi enzyme systems and (b-nicotinamide adenine dinucleotide 2 0-phosphate-reduced tetrasodium salt hydrate (NADPH)) have been deployed on TOCNF film. To initiate the photo reaction, laser light $(488 \mathrm{~nm})$ has been utilized in the system and successful stepwise conversion such as formic acid from adsorbed $\mathrm{CO}_{2}$, formaldehyde from converted formic acid and methanol from converted formaldehyde was achieved with $50 \mathrm{wt} \%, 80 \mathrm{wt} \%$ and $90 \mathrm{wt} \%$, respectively on NADPH/enzyme-loaded Den-TCPP-TOCNF films (See Fig. 5). During the reaction, water molecule worked as an electron donor to TCPP+ and it was oxidized to $\mathrm{O}_{2}$ molecules. The dendrimer played the role of an electron carrier to transfer electrons from TCPP to NADPH and converted to $\mathrm{NADP}^{+}$. In the reaction mechanism of Fig. 5, the photo energy gained by the photosensitizer (TCPP) was transferred to electrons, which were then transferred to the electron carrier (dendrimer) and NADPH, and the electrons from NADPH were provided for the enzymatic reaction for the conversion of $\mathrm{CO}_{2}$. 


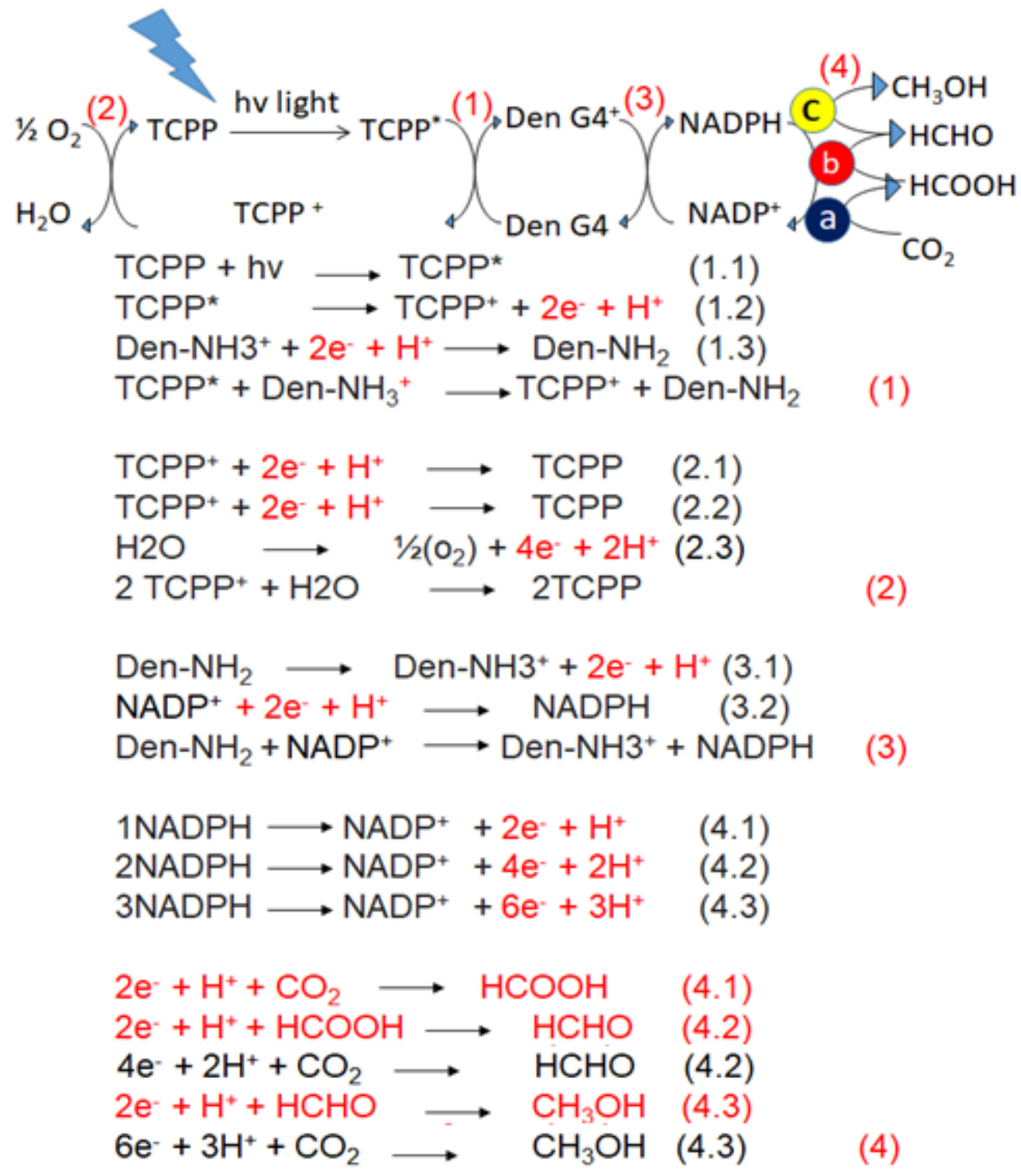

Fig. 5. Photoinduced enzymatic conversion and reaction mechanism of solar fuel on the NADPH/enzyme-loaded Den-TCPP-TOCNF films with immobilized a. FDH; b. AlDH and c. ADH enzymes.

\section{Challenges to solar fuel productions}

Virtually every approach under consideration for the photo-electrochemical reduction of $\mathrm{CO}_{2}$ to fuels by either of ways requires catalysts to facilitate the formation with suitable yields. Development of a more efficient cathode can provide economic competitiveness of $\mathrm{CO}_{2}$ conversion devices by enhancing the energetic efficiency, selectivity, and deactivation of cathode. The utilization of $\mathrm{CO}_{2}$ based on chemical, photochemical and electrochemical technologies has great application potential. Thus, it is expected that 
integrating these routes with the enzymatic route may increase selectivity and productivity [80]. However, the integration of all technologies has challenges.

Currently, the main drawback of this process is the very low quantum yield that keeps the technology in the lab scale. Therefore, most likely, research effort will be focused the design of more efficient photoactive materials [87]. Nevertheless, there are some additional barriers to overcome such as analysis of the product, dealing with impurities, stability of materials and design of major photoreactors [88]. The detection limit of the analytical instruments are quite challenging due to formation of lower concentration of solar fuels. Recently, the optimization of the different methods of analysis has been approached by a combination of GC and HPLC measurements [89]. In which, $\mathrm{CO}_{2}$ is a serious drawback for determining the composition of the products in the gas phase. Recently, many claims for high rate of conversions are suspicious of being affected by undetected impurities. This is because of the lower conversion rate making big differences in the product yields. This is a major reason to follow the GC way to obtain atom economy rather than just focus on yield numbers [90]. The stability of materials is obviously a crucial parameter which affects the engineering aspects but also the economy of the processes. Most of the case degradation/deformation was found which resulted to decrease the conversion ratio. Especially for the case of enzymes, stability for few hours makes big difference for mass utilization [80]. This is a paramount aspect for the practical development of this technology because any progress in enhancing the efficiency may render unsuccessful if the photo catalysts remain active for only a few hours. Finally the design of photoreactors is important to mitigate conversion related challenges. Cloudy days influence the intensity and continuity of the solar lights resulting in big differences in product yield. In addition, considering the limited rates of photocatalytic $\mathrm{CO}_{2}$ reduction, recirculation of the unconverted products will be most likely required and accordingly should be considered in the photoreactor design. All these aspects have been important implications for both the economy and efficiency of the overall process.

\section{Future perspectives}

Photo-electrochemical conversion for $\mathrm{CO}_{2}$ capture, sequestration and utilization provides a green and promising approach to reduce global warming and climate change [91]. Among the existing approaches usually consist of complicated reaction processes or expensive additives such as a noble metals. After the use of noble metals, biodegradability, reusability and cost effectiveness are challengeable [92] which could be solved by bio-degradable products such as enzymes and bio-polymers. Among all methods, enzymatic conversation is successfully utilized for solar fuel production. 
However, significant scientific and technical advances are still required for the largescale utilization of $\mathrm{CO}_{2}$ for solar fuel productions. Thus, considerably more research effort will be stimulated in attempts to discover new low-cost and low-energy input approaches for the regeneration and reuse of enzyme materials [80]. Meanwhile, the utilization of $\mathrm{CO}_{2}$ based on chemical, photochemical and electrochemical technologies has great application potential. Thus, it is expected that integrating these routes with the enzymatic route may increase selectivity and productivity.

Based on the literature survey, the aspects which could help the improvement of conversions are cost effectiveness and efficiency of products to viable applicable in industrial productions. Developing an 'artificial leaf' that collects energy in the same way as a natural leaf is potentially the solution to the problems of sustainability of energy [9396]. To avoid intermittency of solar energy, it is necessary to design systems that directly capture $\mathrm{CO}_{2}$ and convert it into liquid solar fuels, which can be easily stored. There are several research groups namely, Joint Center on Artificial Photosynthesis (JCAP), Photosynthetic Antenna Research Center (PARC), Argonne-Northwestern Solar Energy Research (ANSER) Center, The [French] Alternative Energies and Atomic Energy Commission (CEA), Max Planck Gesellschaft, Water Oxidation Catalysts for BioInspired Photoelectrochemical Cells, Negishi Artificial Photosynthesis Group and Solar Fuels Laboratory Nangang, working on artificial photosynthesis developments [97]. Although it has been explored for many years, much more effort should still be devoted to excavating facile and low-energy routes for $\mathrm{CO}_{2}$ conversion by the use of costeffective technologies.

\section{Acknowledgement}

Authors appreciate the Ministry of Science and Technology (MOST) of Taiwan (R.O.C.) under grant number MOST 106-3113-E-007-002 for the financial support.

\section{References}

[1] P.T. Anastas, M.M. Kirchhoff, Origins, current status, and future challenges of green chemistry, Acc. Chem. Res., 35 (2002) 686-694. https://doi.org/10.1021/ar010065m

[2] P. Anastas, N. Eghbali, Green Chemistry: Principles and Practice, (2009) 301-312.

[3] D. Patel, S. Kellici, B. Saha, Green Process Engineering as the Key to Future Processes, Processes, 2 (2014) 311-332. https://doi.org/10.3390/pr2010311 
[4] I.T. Horvth, P.T. Anastas, Innovations and Green Chemistry, Chem. Rev., 107 (2007) 2169-2173. https://doi.org/10.1021/cr078380v

[5] T. V. Ramachandra, B.H. Aithal, K. Sreejith, GHG footprint of major cities in India, Renew. Sustain. Energy Rev., 44 (2015) 473-495. https://doi.org/10.1016/j.rser.2014.12.036

[6] K. Riahi, D. P. Van Vuuren, E. Kriegler, J. Edmonds, B. C. O'neill, S. Fujimori, W. Lutz, The shared socioeconomic pathways and their energy, land use, and greenhouse gas emissions implications: an overview, Global Environmental Change, 42 (2017) 153-168. https://doi.org/10.1016/j.gloenvcha.2016.05.009

[7] F.A. Rahman, M.M.A. Aziz, R. Saidur, W.A.W.A. Bakar, M.R. Hainin, R. Putrajaya, N.A. Hassan, Pollution to solution: Capture and sequestration of carbon dioxide $\left(\mathrm{CO}_{2}\right)$ and its utilization as a renewable energy source for a sustainable future, Renew. Sustain. Energy Rev., 71 (2017) 112-126. https://doi.org/10.1016/j.rser.2017.01.011

[8] M. Meinshausen, N. Meinshausen, W. Hare, S.C.B. Raper, K. Frieler, R. Knutti, D.J. Frame, M.R. Allen, Greenhouse-gas emission targets for limiting global warming to 2 degrees C., Nature, 458 (2009) 1158-1162. https://doi.org/10.1038/nature08017

[9] J. Rogelj, J. Nabel, C. Chen, W. Hare, K. Markmann, M. Meinshausen, M. Schaeffer, K. Macey, N. Höhne, Copenhagen Accord pledges are paltry, Nature, 464 (2010) 1126-1128. https://doi.org/10.1038/4641126a

[10] L.C. Lau, K.T. Lee, A.R. Mohamed, Global warming mitigation and renewable energy policy development from the Kyoto Protocol to the Copenhagen Accord A comment, Renew. Sustain. Energy Rev. 16 (2012) 5280-5284. https://doi.org/10.1016/j.rser.2012.04.006

[11] J. Rogelj, M. Den Elzen, T. Fransen, H. Fekete, H. Winkler, R. Schaeffer, F. Sha, K. Riahi, M. Meinshausen, Perspective : Paris Agreement climate proposals need boost to keep warming well below $2^{\circ} \mathrm{C}$, Nat. Clim. Chang. 534 (2016) 631-639.

[12] J. Gibbins, H. Chalmers, Carbon capture and storage, Energy Policy. 36 (2008) 4317-4322. https://doi.org/10.1016/j.enpol.2008.09.058

[13] P. Li, S.Y. Pan, S. Pei, Y.J. Lin, P.C. Chiang, Challenges and perspectives on carbon fixation and utilization technologies: An overview, Aerosol Air Qual. Res. 16 (2016) 1327-1344. https://doi.org/10.4209/aaqr.2015.12.0698 
[14] J.D. Figueroa, T. Fout, S. Plasynski, H. McIlvried, R.D. Srivastava, Advances in $\mathrm{CO}_{2}$ capture technology-The U.S. Department of Energy's Carbon Sequestration Program, Int. J. Greenh. Gas Control. 2 (2008) 9-20. https://doi.org/10.1016/S1750-5836(07)00094-1

[15] D.Y.C. Leung, G. Caramanna, M.M. Maroto-Valer, An overview of current status of carbon dioxide capture and storage technologies, Renew. Sustain. Energy Rev. 39 (2014) 426-443. https://doi.org/10.1016/j.rser.2014.07.093

[16] M. Kanniche, R. Gros-Bonnivard, P. Jaud, J. Valle-Marcos, J.M. Amann, C. Bouallou, Pre-combustion, post-combustion and oxy-combustion in thermal power plant for CO2 capture, Appl. Therm. Eng. 30 (2010) 53-62. https://doi.org/10.1016/j.applthermaleng.2009.05.005

[17] M.K. Mondal, H.K. Balsora, P. Varshney, Progress and trends in $\mathrm{CO}_{2}$ capture/separation technologies: A review, Energy. 46 (2012) 431-441. https://doi.org/10.1016/j.energy.2012.08.006

[18] M.M. Hossain, H.I. de Lasa, Chemical-looping combustion (CLC) for inherent $\mathrm{CO}_{2}$ separations-a review, Chem. Eng. Sci. 63 (2008) 4433-4451. https://doi.org/10.1016/j.ces.2008.05.028

[19] C.-H. Yu, A Review of $\mathrm{CO}_{2}$ Capture by Absorption and Adsorption, Aerosol Air Qual. Res. (2012) 745-769. https://doi.org/10.4209/aaqr.2012.05.0132

[20] Z. Yong, V. Mata, A.E. Rodrigues, Adsorption of carbon dioxide at high temperature - a review, Sep. Purif. Technol. 26 (2002) 195-205. https://doi.org/10.1016/S1383-5866(01)00165-4

[21] H. Yang, Z. Xu, M. Fan, R. Gupta, R.B. Slimane, A.E. Bland, I. Wright, Progress in carbon dioxide separation and capture: a review., J. Environ. Sci. (China). 20 (2008) 14-27. https://doi.org/10.1016/S1001-0742(08)60002-9

[22] D. Aaron, C. Tsouris, Separation of CO2 from Flue Gas: A Review, Sep. Sci. Technol. 40 (2005) 321-348. https://doi.org/10.1081/SS-200042244

[23] P. Bernardo, E. Drioli, G. Golemme, Membrane gas separation: 1 review of state of the art, Ind. Chem. Eng. 48 (2009) 4638-63. https://doi.org/10.1021/ie8019032

[24] P. Babu, P. Linga, R. Kumar, P. Englezos, A review of the hydrate based gas separation (HBGS) process forcarbon dioxide pre-combustion capture, Energy. 85 (2015) 261-279. https://doi.org/10.1016/j.energy.2015.03.103

[25] K. Maqsood, A. Mullick, A. Ali, K. Kargupta, S. Ganguly, Cryogenic carbon dioxide separation from natural gas: A review based on conventional and novel 
emerging technologies, Rev. Chem. Eng. 30 (2014) 453-477.

https://doi.org/10.1515/revce-2014-0009

[26] S. J. Baines, R. H. Worden, Geological storage of carbon dioxide. Geological Society, London, Special Publications, 233(2004) 1-6. https://doi.org/10.1144/GSL.SP.2004.233.01.01

[27] J.Q. Shi, S. Durucan, $\mathrm{CO}_{2}$ storage in underground coal seams, Oil \& Gas Science and Technology Rev., 60 (2005) 1-18. https://doi.org/10.2516/ogst:2005037

[28] S. Thomas, Enhanced oil recovery-an overview, Oil \& Gas Science and Technology Rev.,63 (2008) 9-19. https://doi.org/10.2516/ogst:2007060

[29] M. Bentham, G. Kirby, $\mathrm{CO}_{2}$ Storage in Saline Aquifers, Oil \& Gas Science and Technology Rev. 60 (2005) 559-567. https://doi.org/10.2516/ogst:2005038

[30] B. A. Seibel, P. J. Walsh, Potential impacts of $\mathrm{CO}_{2}$ injection on deep-sea biota. Science, 294 (2001) 319-320. https://doi.org/10.1126/science.1065301

[31] V. Anderson, S. Woodhouse, O. F. Graff, J. S. Gudmundson, Hydrates for deep ocean storage of $\mathrm{CO}_{2}$. In Proceedings of the Fifth International Conference on Gas Hydrates, 13, 16, (2005) 1135-1139.

[32] E. Alper, O. Yuksel Orhan, $\mathrm{CO}_{2}$ utilization: Developments in conversion processes, Petroleum. 3 (2016) 109-126. https://doi.org/10.1016/j.petlm.2016.11.003

[33] C.H. Huang, C.S. Tan, A review: $\mathrm{CO}_{2}$ utilization, Aerosol Air Qual. Res. 14 (2014) 480-499. https://doi.org/10.4209/aaqr.2013.10.0326

[34] E. C. Francisco, D. B. Neves, E. Jacob-Lopes, T. T. Franco, (2010). Microalgae as feedstock for biodiesel production: carbon dioxide sequestration, lipid production and biofuel quality." Journal of Chemical Technology and Biotechnology 85 no. 3 (2010) 395-403. https://doi.org/10.1002/jctb.2338

[35] S.-Y. Pan, K.J. Shah, Y.-H. Chen, M.-H. Wang, P.-C. Chiang, Deployment of Accelerated Carbonation Using Alkaline Solid Wastes for Carbon Mineralization and Utilization Toward a Circular Economy, ACS Sustain. Chem. Eng. (2017) acssuschemeng.7b00291. doi:10.1021/acssuschemeng.7b00291.

[36] X. Xiaoding, J.A. Moulijn, Mitigation of $\mathrm{CO}_{2}$ by Chemical Conversion: Plausible Reactions and Promising Products, Energy \& Fuels. 10 (1996) 305-325. https://doi.org/10.1021/ef9501511 
[37] J. Barber, Photosynthetic energy conversion: natural and artificial, Chem. Soc. Rev. 38 (2009) 185-96. https://doi.org/10.1039/B802262N

[38] A. Listorti, J. Durrant, J. Barber, Artificial photosynthesis: Solar to fuel, Nat. Mater. 8 (2009) 929-930. https://doi.org/10.1038/nmat2578

[39] H.B. Gray, Powering the planet with solar fuel, Nat. Chem. 1 (2009) 7. https://doi.org/10.1038/nchem.141

[40] K.J. Shah, T. Imae, Photoinduced enzymatic conversion of $\mathrm{CO}_{2}$ gas to solar fuel on functional cellulose nanofiber films, J. Mater. Chem. A. 5 (2017) 9691-9701. https://doi.org/10.1039/C7TA01861D

[41] J. Barber, P.D. Tran, From natural to artificial photosynthesis., J. R. Soc. Interface. 10 (2013) 20120984. https://doi.org/10.1098/rsif.2012.0984

[42] Alberts, B., Johnson, A., Lewis, J., Raff, M., Roberts, K., \& Walter, P. (2002). Catalysis and the Use of Energy by Cells.

[43] B. Kumar, M. Llorente, J. Froehlich, T. Dang, A. Sathrum, C.P. Kubiak, Photochemical and photoelectrochemical reduction of $\mathrm{CO}_{2}$., Annu. Rev. Phys. Chem. 63 (2012) 541-69. https://doi.org/10.1146/annurev-physchem-032511143759

[44] J.I. Goldsmith, W.R. Hudson, M.S. Lowry, T.H. Anderson, S. Bernhard, Discovery and high-throughput screening of heteroleptic iridium complexes for photoinduced hydrogen production, J. Am. Chem. Soc. 127 (2005) 7502-7510. https://doi.org/10.1021/ja0427101

[45] D.J. Boston, C. Xu, D.W. Armstrong, F.M. Macdonnell, Photochemical reduction of carbon dioxide to methanol and formate in a homogeneous system with pyridinium catalysts, J. Am. Chem. Soc. 135 (2013) 16252-16255. https://doi.org/10.1021/ja406074w

[46] E.B. Cole, P.S. Lakkaraju, D.M. Rampulla, A.J. Morris, E. Abelev, A.B. Bocarsly, Using a One Electron Shuttle for the Multi- electron Reduction of CO 2 to Methanol, J. Amercian Chem. Soc. (2010) 11539-11551.

[47] K. Ma, O. Yehezkeli, E. Park, J.N. Cha, Enzyme Mediated Increase in Methanol Production from Photoelectrochemical Cells and CO2, ACS Catal. 6 (2016) 69826986. https://doi.org/10.1021/acscatal.6b02524

[48] G. Seshadri, C. Lin, A.B. Bocarsly, A new homogeneous electrocatalyst for the reduction of carbon dioxide to methanol at low overpotential, J. Electroanal. Chem. 372 (1994) 145-150. https://doi.org/10.1016/0022-0728(94)03300-5 
[49] J. A. Turner, A Realizable Renewable Energy Future, Sci., 285 (1999) 687-689. https://doi.org/10.1126/science.285.5428.687

[50] L. M. Teesch, J. Adams, Intrinsic interactions between alkaline earth metal ions and peptides: a gas-phase study, J. Am. Chem. Soc. (1990) 4110-4120. https://doi.org/10.1021/ja00167a003

[51] Y. Matsubara, D.C. Grills, Y. Kuwahara, Thermodynamic Aspects of Electrocatalytic $\mathrm{CO} 2$ Reduction in Acetonitrile and with an Ionic Liquid as Solvent or Electrolyte, ACS Catal. 5 (2015) 6440-6452. https://doi.org/10.1021/acscatal.5b00656

[52] C. Janáky, D. Hursán, B. Endrődi, W. Chanmanee, D. Roy, D. Liu, N.R. de Tacconi, B.H. Dennis, K. Rajeshwar, Electro- and Photoreduction of Carbon Dioxide: The Twain Shall Meet at Copper Oxide/Copper Interfaces, ACS Energy Lett. 1 (2016) 332-338. https://doi.org/10.1021/acsenergylett.6b00078

[53] D.H. Apaydin, E. Tordin, E. Portenkirchner, G. Aufischer, S. Schlager, M. Weichselbaumer, K. Oppelt, N.S. Sariciftci, Photoelectrochemical Reduction of CO 2 Using Third-Generation Conjugated Polymers, ChemistrySelect. 1 (2016) 1156-1162. https://doi.org/10.1002/slct.201600326

[54] A.J. Nozik, Photoelectrochemistr Y : Conversion, Ann. Rev. Phys. Chem. 29 (1978) 189-222. https://doi.org/10.1146/annurev.pc.29.100178.001201

[55] H. Ishida, K. Tanaka, T. Tanaka, Electrochemical $\mathrm{CO}_{2}$ reduction catalyzed by ruthenium complexes $[\mathrm{Ru}(\mathrm{bpy}) 2(\mathrm{CO}) 2] 2+$ and $[\mathrm{Ru}(\mathrm{bpy}) 2(\mathrm{CO}) \mathrm{Cl}]+$. Effect of $\mathrm{pH}$ on the formation of CO and HCOO-, Organometallics. 6 (1987) 181-186. https://doi.org/10.1021/om00144a033

[56] Y. Nakamura, R. Hinogami, S. Yae, Y. Nakato, Photoelectrochemical reduction of $\mathrm{CO}_{2}$ at a metal-particle modified p-Si electrode in non-aqueous solutions, Adv. Chem. Conversions Mitigating Carbon Dioxide. 114 (1998) 565-568. https://doi.org/10.1016/S0167-2991(98)80822-7

[57] R. Hinogami, Y. Nakamura, S. Yae, Y. Nakato, An Approach to Ideal Semiconductor Electrodes for Efficient Photoelectrochemical Reduction of Carbon Dioxide by Modification with Small Metal Particles, J. Phys. Chem. B. 102 (1998) 974-980. https://doi.org/10.1021/jp972663h

[58] E.E. Barton, D.M. Rampulla, A.B. Bocarsly, Selective Solar-Driven Reduction of $\mathrm{CO}_{2}$ to Methanol Using a Catalyzed, J. Am. Chem. Soc. 130 (2008) 6342-6344. https://doi.org/10.1021/ja0776327 
[59] J.M. Saveant, Molecular catalysis of electrochemical reactions. Mechanistic aspects, Chem. Rev. 108 (2008) 2348-2378. https://doi.org/10.1021/cr068079z

[60] M.G. Walter, E.L. Warren, J.R. McKone, S.W. Boettcher, Q. Mi, E.A. Santori, N.S. Lewis, Solar Water Splitting Cells, Pubs.Acs.Org. (2010) 6446-6473.

[61] J.M. Smieja, C.P. Kubiak, $\mathrm{Re}($ bipy-tBu $)(\mathrm{CO})_{3} \mathrm{Cl}$-improved catalytic activity for reduction of carbon dioxide: IR-spectroelectrochemical and mechanistic studies, Inorg. Chem. 49 (2010) 9283-9289. https://doi.org/10.1021/ic1008363

[62] N.S. Spinner, J.A. Vega, W.E. Mustain, Recent progress in the electrochemical conversion and utilization of $\mathrm{CO}_{2}$, Catal. Sci. Technol. Catal. Sci. Technol. (2012) 19-28.

[63] R. Kuriki, O. Ishitani, K. Maeda, Unique Solvent Effects on Visible-Light $\mathrm{CO}_{2}$ Reduction over Ruthenium(II)-Complex/Carbon Nitride Hybrid Photocatalysts, ACS Appl. Mater. Interfaces. 8 (2016) 6011-6018. https://doi.org/10.1021/acsami.5b11836

[64] S. Kaneco, H. Katsumata, T. Suzuki, K. Ohta, Photoelectrochemical reduction of carbon dioxide at $\mathrm{p}$-type gallium arsenide and p-type indium phosphide electrodes in methanol, Chem. Eng. J. 116 (2006) 227-231.

https://doi.org/10.1016/j.cej.2005.12.014

[65] P. Luis, Use of monoethanolamine (MEA) for $\mathrm{CO}_{2}$ capture in a global scenario: Consequences and alternatives, Desalination. 380 (2016) 93-99. https://doi.org/10.1016/j.desal.2015.08.004

[66] M. Mikkelsen, M. Jørgensen, F.C. Krebs, The Teraton Challenge. A Review of Fixation and Transformation of Carbon Dioxide, Energy Environ. Sci. 3 (2010) 43-81. https://doi.org/10.1039/B912904A

[67] B. Aurian-Blajeni, M. Halmann, J. Manassen, Electrochemical measurement on the photoelectrochemical reduction of aqueous carbon dioxide on $\mathrm{p}$-Gallium phosphide and p-Gallium arsenide semiconductor electrodes, Sol. Energy Mater. 8 (1983) 425-440. https://doi.org/10.1016/0165-1633(83)90007-2

[68] J. A. Herron, J. Kim, A. A. Upadhye, , G. W. Huber, C. T. Maravelias, A general framework for the assessment of solar fuel technologies." Energy \& Environmental Science 8, no. 1 (2015): 126-157. https://doi.org/10.1039/C4EE01958J

[69] K. Hara, Electrocatalytic Formation of $\mathrm{CH}_{4}$ from $\mathrm{CO}_{2}$ on a Pt Gas Diffusion Electrode, J. Electrochem. Soc. 144 (1997) 539. https://doi.org/10.1149/1.1837445 
[70] E. Kecsenovity, B. Endrödi, P.S. Tóth, Y. Zou, R.A.W. Dryfe, K. Rajeshwar, C. Janáky, Enhanced Photoelectrochemical Performance of Cuprous Oxide/Graphene Nanohybrids, J. Am. Chem. Soc. 139 (2017) 6682-6692.

https://doi.org/10.1021/jacs.7b01820

[71] Z. Guo, T. Liu, W. Li, C. Zhang, D. Zhang, Z. Pang, Carbon Supported OxideRich Pd-Cu Bimetallic Electrocatalysts for Ethanol Electrooxidation in Alkaline Media Enhanced by $\mathrm{Cu} / \mathrm{CuOx}$, Catalysts. 6 (2016) 62. https://doi.org/10.3390/catal6050062

[72] B. Parida, S. Iniyan, R. Goic, A review of solar photovoltaic technologies, Renew. Sustain. Energy Rev. 15 (2011) 1625-1636. https://doi.org/10.1016/j.rser.2010.11.032

[73] K. Ogura, M. Yamada, M. Nakayama, N. Endo, Electrocatalytic Reduction of $\mathrm{CO}_{2}$ to Worthier Compounds on a Functional Dual-Film Electrode with a Solar Cell as the Energy Source, Adv. Chem. Conversions Mitigating Carbon Dioxide. 114 (1998) 207-212. https://doi.org/10.1016/S0167-2991(98)80745-3

[74] M. Halmann, M. Ulman, B. Aurian-Blajeni, Photochemical solar collector for the photoassisted reduction of aqueous carbon dioxide, Sol. Energy. 31 (1983) 429431. https://doi.org/10.1016/0038-092X(83)90145-7

[75] A. Bard, M.A. Fox, Artificial Photosynthesis: Solar Splitting of Water to Hydrogen and Oxygen, J. Chem. Inf. Model. 53 (2013) 1689-1699.

[76] A. Goeppert, M. Czaun, J.-P. Jones, G.K. Surya Prakash, G.A. Olah, Recycling of carbon dioxide to methanol and derived products - closing the loop, Chem. Soc. Rev. 43 (2014) 7995-8048. https://doi.org/10.1039/C4CS00122B

[77] M. Rahimnejad, A. Adhami, S. Darvari, A. Zirepour, S.E. Oh, Microbial fuel cell as new technol ogy for bioelectricity generation: A review, Alexandria Eng. J. 54 (2015) 745-756. https://doi.org/10.1016/j.aej.2015.03.031

[78] K. Ogura, Catalytic Conversion of Carbon Monoxide and Carbon Dioxide into Methanol with Photocells, J. Electrochem. Soc. 134 (1987) 2749. https://doi.org/10.1149/1.2100281

[79] K. Ogura, H. Uchida, Electrocatalytic reduction of carbon dioxide to methanol. Part 5. Relationship between the ability of metal complexes to engage in homogeneous catalysis and their co-ordination chemistry. Journal of the Chemical Society, Dalton Transactions, 6 (1987), 1377-1380. https://doi.org/10.1039/dt9870001377 
[80] J. Shi, Y. Jiang, Z. Jiang, X. Wang, X. Wang, S. Zhang, P. Han, C. Yang, Enzymatic conversion of carbon dioxide, Chem. Soc. Rev. Chem. Soc. Rev. 44 (2015) 5981-6000. https://doi.org/10.1039/C5CS00182J

[81] N. V. D. Long, J. Lee, K.-K. Koo, P. Luis, M. Lee, Recent Progress and Novel Applications in Enzymatic Conversion of Carbon Dioxide, Energies. 10 (2017) 473. https://doi.org/10.3390/en10040473

[82] B.R. Crable, C.M. Plugge, M.J. McInerney, A.J.M. Stams, Formate formation and formate conversion in biological fuels production., Enzyme Res. 2011 (2011) 532536. https://doi.org/10.4061/2011/532536

[83] Y. Amao, Solar fuel production based on the artificial photosynthesis system, ChemCatChem. 3 (2011) 458-474. https://doi.org/10.1002/cctc.201000293

[84] T. Noji, K. Kawakami, J.R. Shen, T. Dewa, M. Nango, N. Kamiya, S. Itoh, T. Jin, Oxygen-Evolving Porous Glass Plates Containing the Photosynthetic Photosystem II Pigment-Protein Complex, Langmuir. 32 (2016) 7796-7805. https://doi.org/10.1021/acs.langmuir.6b02106

[85] K.J. Shah, T. Imae, A. Shukla, Selective capture of $\mathrm{CO}_{2}$ by poly(amido amine) dendrimer-loaded organoclays, RSC Adv. 5 (2015) 35985-35992. https://doi.org/10.1039/C5RA04904K

[86] K.J. Shah, T. Imae, Selective Gas Capture Ability of Gas-Adsorbent-Incorporated Cellulose Nanofiber Films, Biomacromolecules. 17 (2016) 1653-1661. https://doi.org/10.1021/acs.biomac.6b00065

[87] J.H. Montoya, L.C. Seitz, P. Chakthranont, A. Vojvodic, T.F. Jaramillo, J.K. Nørskov, Materials for Solar Fuels and Chemicals, Nat. Mater. 16 (2017) 70-81. https://doi.org/10.1038/nmat4778

[88] A. Víctor, D. P. Serrano, J. M. Coronado, Current Challenges of $\mathrm{CO}_{2}$ Photocatalytic Reduction Over Semiconductors Using Sunlight. In From Molecules to Materials (171-191). Springer International Publishing (2015).

[89] J. Hong, W. Zhang, J. Ren, R. Xu, Photocatalytic reduction of $\mathrm{CO}_{2}$ : a brief review on product analysis and systematic methods, Anal. Methods. 5 (2013) 1086-1097. https://doi.org/10.1039/c2ay26270c

[90] C.-J. Li, B.M. Trost, Green chemistry for chemical synthesis., Proc. Natl. Acad. Sci. U. S. A. 105 (2008) 13197-13202. https://doi.org/10.1073/pnas.0804348105 
[91] S. Bensaid, G. Centi, E. Garrone, S. Perathoner, G. Saracco, Towards artificial leaves for solar hydrogen and fuels from carbon dioxide, ChemSusChem. 5 (2012) 500-521. https://doi.org/10.1002/cssc.201100661

[92] S. Lata, P.K. Singh, S.R. Samadder, Regeneration of adsorbents and recovery of heavy metals: a review, Int. J. Environ. Sci. Technol. 12 (2015) 1461-1478. https://doi.org/10.1007/s13762-014-0714-9

[93] J. H. Alstrum-Acevedo, M. K. Brennaman, T. J. Meyer, Chemical approaches to artificial photosynthesis. 2. Inorganic Chemistry, 44,20 (2005), 6802-6827. https://doi.org/10.1021/ic050904r

[94] D. Gust, T.A. Moore, A.L. Moore, Solar fuels via artificial photosynthesis, Acc.Chem.Res. 42 (2009) 1890-1898. https://doi.org/10.1021/ar900209b

[95] D.G. Nocera, The artificial leaf, Acc. Chem. Res. 45 (2012) 767-776. https://doi.org/10.1021/ar2003013

[96] Y. Tachibana, L. Vayssieres, J. R. Durrant, Artificial photosynthesis for solar water-splitting. Nature Photonics, 6,8 (2012) 511-518. https://doi.org/10.1038/nphoton.2012.175

[97] T.A. Faunce, Future Perspectives on Solar Fuels, Mol. Sol. Fuels. (2012) 506-528. 